\title{
POR UMA TEORIA DA NARRATOLOGIA JURÍDICA: DE QUE MODO A TEORIA LITERÁRIA PODE SERVIR À COMPREENSÃO E CRÍTICA DO DIREITO
}

\author{
FOR A THEORY OF LEGAL NARRATOLOGY:
}

HOW CAN A LITERARY THEORY BE USEFUL FOR THE

COMPREHENSION AND CRITICISM OF LAW

Douglas Antônio Rocha Pinheiro*

RESUMO: A partir da utilização do dialogismo pelo historiador Carlo Ginzburg na análise de autos inquisitoriais, especialmente no caso dos benandanti, o artigo discute a possibilidade de uma leitura do Direito baseada nas categorias relativas à Teoria Literária, especialmente as defendidas por Mikhail Bakhtin, bem como sua capacidade de oportunizar uma nova reflexão sobre o fenômeno jurídico.

PALAVRAS-CHAVE: Narrativa jurídica. Dialogismo. Plurilinguismo. Polifonia.

ABSTRACT: From historian Carlo Ginzburg's use of dialogism in the analysis of inquisitorial papers, especially in the benandanti case, the article aims to discuss the possibility of a legal reading based on the categories related to literary theory, above all those Mikhail Bakhtin holds, as well as their capacity to provide a new reflection on the legal phenomenon.

KEYWORDS: Juridical narrative. Dialogism. Heteroglossia. Polyphony.

* Mestre e Doutorando em Direito, Estado e Constituição pela Universidade de Brasília. Professor Assistente da Universidade Federal de Goiás. Contato: darpinheiro@gmail.com. 


\section{NEM JURISTA, NEM LITERATO: UM HISTORIADOR}

Em 1966, o historiador Carlo Ginzburg publicou seu primeiro livro. Fruto de uma minuciosa pesquisa realizada no Arquivo da Cúria Arquiepiscopal de Udine, que conserva o material relativo ao Santo Ofício de Aquileia e de Concórdia, a obra reconstruiu a mentalidade dos chamados andarilhos do bem (benandanti), grupo de indivíduos da região italiana do Friul que, durante os séculos XVI e XVII, nas noites dos Quatro Tempos ${ }^{1}$, entravam em letargia e saíam "em espírito" ou para ver os mortos ou para combater contra os feiticeiros pela abundância nas colheitas (GINZBURG, 2007a).

A identificação de traços de uma religiosidade popular em documentos oficiais redigidos com cautela considerável, como os autos inquisitoriais, só foi possível na medida em que o relato dos benandanti, revelador de uma realidade desconcertante e não ajustável aos esquemas demonológicos já conhecidos, gerou um registro sem grandes deformações, graças ao misto de espanto e curiosidade que causava nos inquisidores. Assim, a discrepância presente em tais documentos entre as perguntas dos inquisidores e as respostas dos acusados, que não poderia ser atribuída a interrogatórios sugestivos nem à tortura, trouxe à tona "um estrato profundo de crenças populares substancialmente autônomas" (GINZBURG, 2008, p. 19).

Apesar de bem recebido, o livro sofreu algumas críticas por ter dado insuficiente atenção aos inquisidores e à atitude deles perante a feitiçaria, o que gerou um desequilíbrio na pesquisa admitido pelo próprio Ginzburg em um pós-escrito de 1972 (2007a, p. 15). Posteriormente, em 1989, o historiador, de algum modo, supriu essa lacuna por meio do artigo $O$ inquisidor como antropólogo ${ }^{2}$, texto no qual voltava a mencionar os processos inquisitoriais desencadeados contra os benandanti; dessa vez, porém, a utilização de tais processos foi justificada por meio da noção de romance polifônico defendida por Mikhail Bakhtin.

Fazendo a ressalva de que o seu artigo não era o espaço adequado para discutir "as observações de Bakhtin sobre o gênero específico em que deveriam ser inseridos os romances de Dostoiévski" e admitindo que as personagens que se enfrentavam em tais interrogatórios não se encontravam no mesmo plano do poder, Ginzburg defendeu que, ainda assim, em alguns momentos, os textos deles decorrentes apresentavam alguma polifonia. Para o historiador, o desacordo entre a narrativa das batalhas noturnas dos

1 “Chamam-se ‘Quatro Tempos' os três dias de jejum prescritos pelo calendário eclesiástico durante a primeira semana da Quaresma (Tempos da primavera), a oitava de Pentecostes (Tempos de verão), a terceira semana de Setembro (Tempos de outono) e a terceira semana do Advento (Tempos de inverno)" (GINZBURG, 2007a, p. 217).

20 texto original italiano foi publicado no livro Studi in onore di Armando Saitta dei suoi allievi pisani organizado por R. Pozzi e A. Prosperi. A primeira tradução brasileira, feita por Jônatas Batista Neto, foi publicada na Revista Brasileira de História de set./1990-fev./1991. Recentemente, em 2007, o texto recebeu nova tradução e foi acrescido de um post scriptum feito pelo próprio Ginzburg, tendo sido incluído numa coletânea de artigos seus publicada sob o título O fio e os rastros (2007b). 
friulanos e a descrição tradicional de sabá a que estavam habituados os inquisidores gerou desconforto e surpresa tais que permitiram o registro de vozes distintas, diferentes e até opostas nos processos inquisitoriais, vozes que não significavam simples eco a perguntas indutivas e que fizeram desse interrogatório um texto polifônico (GINZBURG, 2007b, p. 286-287).

Tal releitura feita pelo historiador enseja algumas reflexões. 0 texto de Bakhtin sobre os problemas da poética de Dostoiévski só foi publicado na Itália em 1968 sob o título Dostoievskij: poetica e stilistica (SCHNAIDERMAN, 1973, p. XX). Isso explica a inexistência de referências bakhtinianas no livro sobre os benandanti, publicado dois anos antes. Na verdade, a primeira citação à Bakhtin na obra de Ginzburg somente acontece em seu segundo livro - O queijo e os vermes, publicado na Itália em $1976^{3}$.

Em tal livro, Ginzburg assumidamente se valeu da tese bakhtiniana sobre a existência, na Europa pré-industrial, de uma circularidade entre a cultura das classes dominantes e a cultura das classes subalternas, feita de influências recíprocas entre ambos os planos, quer de baixo para cima, quer de cima para baixo. Com isso, justificava como o desconhecido moleiro Domenico Scandella, também chamado Menocchio, poderia sustentar perante o Santo Ofício opiniões surpreendentemente convergentes com as defendidas por grupos de sofisticados intelectuais de sua época (GINZBURG, 2008).

Porém, após ter se valido das teses de Bakhtin sobre Rabelais e Dostoiévski para analisar processos inquisitoriais, o historiador não manifestou aproximação em relação aos demais textos do teórico russo. Prova disso é que ao fazer uma crítica ao formalismo mecanicista de Chklovski, por reduzir o estranhamento a mero procedimento literário ${ }^{4}$, Ginzburg (2001, p. 15-41) voltou a citar o Bakhtin da cultura popular, em nota marginal, desconsiderando totalmente o Bakhtin da teoria literária ${ }^{5}$. Desse modo, por não justapor

3 Em nota de rodapé, Ginzburg (2008, p. 201) admitiu: "Usei a tradução francesa de Bakhtin: L'oeuvre de François Rabelais et la culture populaire au Moyen Age et sous la Renaissance (Paris, 1970)". Num artigo publicado em 1996 - Estranhamento: pré-história de um procedimento literário - que também faz menção à reflexão bakhtiniana da obra de Rabelais, a referência à tradução francesa deu lugar à publicação moscovita de 1965 e à versão italiana de 1979 (GINZBURG, 2001, p. 231). Por seu conhecido rigor quanto às fontes, parece improvável que Ginzburg tenha tido acesso ao texto original de Bakhtin antes de lançado $O$ queijo e os vermes. Assim, é bem possível que a versão francesa tenha marcado, de fato, o primeiro contato com a obra do filósofo russo.

4 "E eis que para devolver a sensação de vida, para sentir os objetos, para provar que pedra é pedra, existe o que se chama arte. O objetivo da arte é dar a sensação do objeto como visão e não como reconhecimento; o procedimento da arte é o procedimento da singularização dos objetos e o procedimento que consiste em obscurecer a forma, aumentar a dificuldade e a duração da percepção. $\mathrm{O}$ ato da percepção em arte é um fim em si mesmo e deve ser prolongado; a arte é um meio de experimentar o devir do objeto, o que é já 'passado' não importa para a arte" (CHKLOVSKI, 1973, p. 45).

$5 \mathrm{O}$ artigo em questão é o mesmo referido na nota anterior. Oportuno lembrar que no texto $O$ problema do conteúdo, do material e da forma na criação literária, escrito entre 1923/1924 e incluído na edição brasileira do livro Questões de literatura e de estética, Bakhtin (1990a, p. 60-61) já fazia uma crítica direta ao estranhamento de Chklovski sob argumento de que o procedimento defendido pelo formalista levava em conta apenas a palavra e isso por meio de uma destruição de sua série semântica habitual. Bakhtin argumentava que, desse modo, perdia-se 
uma quantidade maior de obras do filósofo ${ }^{6}$ russo, Ginzburg acabou identificando polifonia onde, na verdade, existiu plurilinguismo - equívoco que será tratado abaixo.

Por ora, cabe apenas destacar um outro pós-escrito de Ginzburg, dessa vez aposto ao final do já mencionado artigo sobre os inquisidores. Nele o historiador observa que durante sua visita a Moscou, em novembro de 2003, um grupo que trabalha com a história das perseguições desencadeadas na era stalinista entreveu, a partir da percepção do dialogismo nos processos inquisitoriais, a possibilidade de se identificar o registro de vozes dissonantes nos autos dos processos movidos durante a fase mais dura da repressão interna soviética (GINZBURG, 2007b, p. 293). É justamente tal perspectiva que abre caminho à possibilidade reflexiva do presente artigo.

Assim, embora a leitura de Ginzburg acerca da polifonia em Dostoiévski seja tardia ou, pelo menos, não contemporânea aos estudos dos processos inquisitoriais com os quais, posteriormente, foi vinculada e apesar da indistinção com que o historiador tratou dialogismo, plurilinguismo e polifonia ${ }^{7}$, é importante destacar que foi ele quem demonstrou com clareza a possibilidade de se utilizar categorias da teoria literária - especialmente as desenvolvidas por Mikhail Bakhtin - para analisar processos judiciais.

Demonstrada a possibilidade, resta justificar a conveniência de tal utilização. Para tanto, já de antemão, apontam-se as possíveis críticas à consideração do direito como uma narrativa, fazendo-o em reconhecimento ao dialogismo como postura necessária às defesas argumentativamente sustentadas na esfera pública, e, ato contínuo, refutam-se essas mesmas críticas, para que os debates suscitados pelo presente artigo tenham novos (ou, ao menos, outros) pontos de partida.

\section{POR UMA TEORIA NARRATIVA DO DIREITO}

Todo discurso é marcado por uma dialogicidade interna que decorre, em certa medida, da influência de uma resposta antecipada, um discurso-resposta que, mesmo

a dimensão de isolamento do conteúdo do objeto estético em relação ao acontecimento único e aberto da existência, ou seja, de sua dimensão ético-cognitiva - crítica bastante próxima a de Ginzburg. Posteriormente, em texto escrito em 1928 e publicado, em inglês, sob o título The formal method in literary scholarship, Bakhtin/Medvedev (1991, p. 59-61), de forma ainda mais incisiva, chama o estranhamento formalista de niilista, na medida em que deixa de explorar o caráter polissêmico da linguagem (dimensão positiva de construção de significados capaz de potencializar a própria palavra), para se centrar na simples negação de velhos significados.

6 Bakhtin sempre se considerou um filósofo. Todavia, a visibilidade obtida pelos seus textos sobre linguística e teoria literária, acompanhada da descoberta tardia e fragmentada de sua produção mais filosófica, acabaram encobrindo, por muito tempo, sua vocação primeira (SHATSKIKH, 2007, p. 305).

7 No artigo As vozes do outro - Uma revolta indígena nas ilhas Marianas, publicado em grego, no volume 12 da revista Ta Istoriká - Historica, em junho de 1995, e depois integrado ao livro Relações de força, embora Ginzburg demonstre muita propriedade na explicação do conceito polifonia, ao aplicá-lo à análise documental a que se propõe no artigo novamente o utiliza equivocadamente no lugar do adequado plurilinguismo. Agradeço a Raphael Marques por me chamar a atenção para tal fato. 
não tendo sido dito ainda, já é esperado, pressentido e presentificado, orientando, desde agora, a formulação do enunciado que se profere (BAKHTIN, 1990b, p. 89). Assim, mesmo que as críticas cogitadas não se vinculem a algum autor em particular, tal prática dialógica é fundamental para tornar o discurso mais vivo e corrente.

Uma primeira reação à tese da narratologia jurídica poderia partir do pressuposto de que a aproximação entre direito e literatura não passaria de um exercício metafórico de linguagem. Desse modo, como metáfora, tal relação acabaria se tornando não essencial, na medida em que qualquer outra vinculação entre imagens seria possível: por exemplo, direito como organismo ou direito como mecanismo. Ora, ainda que se tratasse de mera metáfora, tal aproximação já permitiria alguma reflexão.

Afinal, a metáfora - que não tem um valor objetivo em si, mas serve de crisol de visões de mundo, culturas e tradições específicas, hermeneuticamente conjugadas - preserva a capacidade criadora da linguagem e, por consequência, do próprio direito. Não sem motivo, Alessandro Giuliani aconselhava que os juristas se aventurassem pelo campo das metáforas a fim de adquirir conhecimento sobre termos e institutos jurídicos:

Toda a história do pensamento jurídico poderia ser estudada sob o ponto de vista da linguagem, como uma sucessão de metáforas: bastaria examinar qualquer uma das controvérsias da ciência jurídica para ver como as diversas soluções são condicionadas pelas metáforas admitidas, pelas similitudes, pelo recurso ao exemplo. Podemos encontrar a confirmação da tese de Blumenberg, sobre a existência de palavras-chave que são metáforas absolutas, no sentido que resiste a uma resolução em termos lógicos: a impossibilidade de consenso sobre o termo "direito" seria disso testemunha. O trabalho do jurista é de aperfeiçoamento de metáforas, clarificação da linguagem ${ }^{8}$.

Para Vespaziani (2009), porém, a incursão do jurista nesta seara assume uma dimensão ética para além da cognitiva. Baseando-se no argumento de que a metáfora não corresponde apenas a uma figura retórica dentre outras, mas que integra a própria estrutura do discurso jurídico, o autor italiano defende que seu estudo permitiria desvelar os possíveis projetos ideológicos ocultos por detrás de uma linguagem que indevidamente se apresenta como neutra. Superado, pois, o argumento da improdutividade da metáfora, permanece o da não essencialidade da relação entre direito e literatura.

Vera Karam de Chueiri demonstra, porém, que igualmente ele não subsiste. Segundo Chueiri, o positivismo jurídico, ao defender uma compreensão descritiva do direito, não consegue dar conta de sua dimensão prescritiva. Daí a imprescindibilidade

8 Tradução feita pelo autor do artigo. No original: "tutta la storia del pensiero giuridico potrebbe essere studiata dal punto di vista del linguaggio, come un susseguirsi di metafore: basterebbe esaminare una qualsiasi delle controversie della scienza giuridica per vedere come le diverse soluzioni siano condizionate dalle metafore accettate, dalle similitudini, dal ricorso all'esempio. Potremmo trovare la conferma della tesi del Blumenberg ossia della esistenza di termini chiave che sono metafore assolute, nel senso che mostrano resistenza ad una risoluzione in termini logici: l'impossibilità di accordo sul termine 'diritto' ne sarebbe una testimonianza. Il lavoro del giurista è correzione di metafore, chiarificazione del linguaggio" (GIULIANI apud VESPAZIANI, 2009, p. 2). 
de uma teoria narrativa do direito, na medida em que ela poderia, genuinamente, mediar descrição e prescrição, visto que "alargaria o campo da ação (da prática) e anteciparia considerações éticas na própria estrutura do ato de narrar”. Desse modo, por consequência, a crítica literária poderia ser utilizada pelos juristas como forma de melhor "compreender e avaliar o direito, as instituições jurídicas, os procedimentos jurisdicionais e a justiça e, nesse sentido, a própria narrativa da obra literária" serviria "para melhor compreender a narrativa jurídica (as sentenças judiciais, por exemplo)" (CHUEIRI, 2007, p. 120).

Uma segunda reação poderia se fundar no argumento de que um olhar estético sobre o direito colocaria em risco seu compromisso ético. Tal crítica não é de todo suposta; afinal, preocupação semelhante já foi externada em relação à história. Ginzburg, por exemplo, embora não negue uma dimensão literária no trabalho do historiador (GINZBURG, 1990, p. 255), teme que o gradativo esmaecimento das fronteiras entre narrativas ficcionais e históricas comprometa o princípio histórico da realidade ${ }^{9}$, do que decorreriam efeitos éticos desastrosos - como, no limite exemplar, a validação da tese Faurisson de que campos de concentração nazistas não teriam existido (GINZBURG, 2007b, p. 8 e 215-217).

Ora, antes de tudo é preciso ressaltar que uma teoria narrativa do direito não corresponde a uma teoria ficcional do direito. Considerar uma sentença judicial como um equivalente funcional da narrativa literária significa demonstrar como pessoas e fatos reais são, de algum modo, esteticizados quando passam a integrar a tessitura criativa de uma decisã ${ }^{10}$. A criatividade do intérprete não pode ser entendida como recurso à invenção pura e simples, tão receada por Ginzburg (2007b, p. 334).

De algum modo, mesmo na literatura não existe um estatuto absoluto da invenção.

Toda criação é concatenada tanto por suas leis próprias quanto pelas leis do material sobre o qual ela trabalha. Toda criação é determinada por seu objeto e sua estrutura e por isto não admite o arbítrio e, em essência, nada inventa mas apenas descobre aquilo que é dado no próprio objeto (BAKHTIN, 2008, p. 73).

Isso não significa que o objeto estético já se encontra pronto em algum lugar e de algum modo à espera de ser descoberto, mas que pressupõe tanto um conteúdo (a realidade do conhecimento e do ato), que ele apenas transfigura e formaliza (BAKHTIN, 1990a, p. 49 e 69), quanto os limites do material (palavra) e da forma (modo de isolamento

9 Não se debate, no presente artigo, a pertinência do princípio histórico da realidade defendido por Ginzburg. Mas, apenas para suscitar uma inquietação, parece que o referido princípio aponta para uma objetividade localizada para além do discurso de justificação, o que hermeneuticamente não se sustenta.

10 “A argumentação jurídica e as decisões judiciais passaram a ser compreendidas como atividades interpretativas que permitem aos que as exercitam usar a sua criatividade, ainda que nos limites de valores que são, num primeiro momento, estéticos" (CHUEIRI, 2007, p. 120). 
da realidade, conferindo-lhe algum acabamento). A originalidade e a singularidade do campo estético não decorreriam, pois, dele criar sua própria realidade, mas de celebrar, ornar e evocar uma realidade preexistente ético-cognitiva, apresentando-a transformada (BAKHTIN, 1990a, p. 33).

Bakhtin não desconhece a existência de obras desconectadas com o mundo ${ }^{11}$. Todavia, tais expressões de arte somam-se à vida de forma mecânica e externa, deixando, assim, de constituir uma unidade interna e arquitetônica com o próprio homem. Naquele que é considerado seu primeiro texto, datado de 1919, o filósofo russo, antecipando o debate europeu sobre o papel da arte, ocorrido no pós-Segunda Guerra, já afirmava que a "inspiração" não podia justificar a irresponsabilidade, pois a "inspiração que ignora a vida é ela mesma ignorada pela vida, não é inspiração mas obsessão" (BAKHTIN, 2006a, p. XXXIV). Assim, somente na unicidade da responsabilidade é que arte e vida poderiam se encontrar e mutuamente se iluminar, na medida em que uma ensejaria a visão excedente ${ }^{12}$ sobre a outra, gerando um contínuo ato reflexivo - ou, segundo a terminologia bakhtiniana, ato responsível (um misto de dialogicamente responsivo e de eticamente responsável).

Além dessa própria impossibilidade estética de exclusão da esfera ética, o enunciado jurídico ainda se submete a um complexo controle discursivo intersubjetivo, que ocorre primeiramente dentro do processo, integrando o juiz e as partes, via contraditório, mas que, depois, acontece em círculos comunicativos de deliberação pública cada vez mais ampliados: os tribunais, para onde a parte insatisfeita recorre; outros juízes e doutrinadores, quando a decisão isolada se converte em precedente judicial ou referencial didático; a mídia, ampliando o alcance da decisão para um auditório não jurídico; e, por fim, a sociedade em geral quando o caso se converte em assunto cotidiano (VAN HOECKE apud MELLO, 2004, p. 190-191). Restringe-se, assim, a possibilidade ficcional do direito - não a sua narratividade.

Uma terceira reação poderia apontar que o direito, mesmo conservando sua dimensão ética, perderia sua capacidade crítica quando lido pelas lentes da teoria literária,

11 “Existem obras que realmente não tem nada a ver com o mundo, mas somente com a palavra 'mundo' num contexto literário, obras que nascem, vivem e morrem nas folhas das revistas, sem ultrapassar as páginas das edições periódicas contemporâneas e sem nos conduzir a nada que se encontre além dos seus limites. O elemento ético-cognitivo do conteúdo, que apesar de tudo lhes é indispensável como elemento constitutivo da obra de arte, não é haurido diretamente por elas do mundo do conhecimento e da realidade ética do ato, mas, das outras obras de arte, ou é construído por analogia com elas" (BAKHTIN, 1990a, p. 37-38).

12 "Porque em qualquer situação ou proximidade que esse outro que contemplo possa estar em relação a mim, sempre verei e saberei algo que ele, da sua posição fora e diante de mim, não pode ver: as partes de seu corpo inacessíveis ao seu próprio olhar - a cabeça, o rosto, e sua expressão -, o mundo atrás dele, toda uma série de objetos e relações que, em função dessa ou daquela relação de reciprocidade entre nós, são acessíveis a mim e inacessíveis a ele. (...) Esse excedente da minha visão (...) é condicionado pela singularidade e pela insubstitubilidade do meu lugar no mundo" (BAKHTIN, 2006b, p. 21). 
visto que esta enfatizaria sobremaneira os aspectos formais da poética, tais como: ritmo, entonação, articulação, motivo, gênero, dentre outros. De fato, tais estudos seriam possíveis. Todavia, apontando para uma análise composicional do material, eles abordariam, apenas, um dos elementos constitutivos do objeto estético.

Um olhar que se volte para o todo da obra de arte deve considerá-la em sua forma arquitetônica, percebendo, para além do material, a tensão constante entre forma e conteúdo: este opõe-se àquela como algo passivo que dela precisa, "algo receptivo, acolhedor, englobante"; porém, tão logo deixe de ser ativo na forma, "o conteúdo que a forma aquietou e concluiu revolta-se e aparece na sua significação pura e ético-cognitiva" (BAKHTIN, 1990a, p. 58). Assim, a percepção do objeto estético se dá por meio de uma relação ativa que faz com que o observador ingresse como criador no que vê, ouve e pronuncia, superando, assim, o caráter determinado, material e extraestético da forma "ela deixa de existir no nosso exterior como um material percebido e organizado de modo cognitivo, transformando-se na expressão de uma atividade valorizante que penetra no conteúdo e o transforma" (BAKHTIN, 1990a, p. 59).

Ronald Dworkin, por outras vias, ao estabelecer uma comparação entre a prática jurídica e o exercício literário, valendo-se da metáfora ${ }^{13}$ do romance em cadeia (chain novel), demonstrou quão produtiva para o direito pode ser tal tensão forma-conteúdo. O romance em cadeia corresponderia a uma narrativa em série, escrita por um grupo distinto de romancistas. Estabelecida a ordem da composição de forma aleatória, por meio da sorte, cada autor escreveria um capítulo, ao fim do qual confiaria a continuidade da obra ao escritor imediatamente subsequente.

Cada romancista, excepcionado o primeiro, teria a dupla responsabilidade de interpretar e criar, visto que o capítulo que lhe caberia escrever precisaria partir dos elementos gerais já previamente trabalhados pelos demais autores, tais como gênero, trama, tema, objetivo, personagens, espaço, tempo. Deveria verificar, pois, a plausibilidade de sua contribuição literária e, havendo mais de uma escrita possível, qual se justificaria melhor no contexto geral da obra (DWORKIN, 1999, p. 276-278; 2005, p. 235-237).

Do mesmo modo, cada juiz, como um romancista dessa cadeia, diante da unicidade dos casos que lhe são apresentados, extraídos da complexa e aberta realidade éticocognitiva do mundo, deve saber conjugar um conteúdo de justiça, sem desmerecer formas de restrição garantidoras da segurança jurídica ${ }^{14}$, observáveis por meio de uma

${ }^{13}$ Dworkin, embora tenha dado grande contribuição aos estudos jurídico-literários, considera a aproximação entre direito e literatura como sendo metafórica. Afinal, segundo ele, o direito não pode ser pensado como um "empreendimento artístico", mas sim, como "empreendimento político" (DWORKIN, 2005, p. 239). De qualquer modo, tal posicionamento já foi analisado anteriormente no presente artigo.

${ }^{14}$ Tal tensão, na verdade, mais que opositiva é mutuamente constitutiva. A forma, ao estabelecer uma certa segurança jurídica, pode igualmente garantir a justiça - a construção histórica do habeas corpus é exemplo disso (cf. PAIXÃO, 2008, p. 29-30). 
postura dialógica ${ }^{15}$ quer com as decisões proferidas anteriormente (o que é mais forte no sistema norte-americano), quer com um texto constitucional de referência (tal qual o sistema brasileiro).

Não há, pois, como pensar a forma desconsiderando o conteúdo e vice-versa. Uma postura contrária a tal entendimento parece ser tributária da mesma compreensão que ignora o constante trânsito comunicacional verificável entre os distintos campos de conhecimento, por considerá-los territórios bem determinados. Na verdade, todo ato cultural está inteiramente situado sobre fronteiras. Fora delas, o ato torna-se vazio e superficial; sobre elas, em contato com outros pontos de vista criadores, ele afirma sua singularidade criativa, encontra seu fundamento e sua justificação sólida (BAKHTIN, 1990a, p. 29).

Bakhtin tinha plena compreensão dessa realidade, razão por que estudá-lo pode se tornar "especialmente proveitoso quando os limites rigidamente estabelecidos entre disciplinas acadêmicas e campos de estudo são redefinidos ou postos em xeque"16. Parece, pois, cada vez mais, que a utilização das categorias bakhtinianas como instrumental de análise de processos judiciais, como fez Ginzburg em relação aos autos inquisitoriais, é plenamente justificável. Acima, porém, afirmou-se que o historiador italiano equivocou-se quanto à diferenciação de tais categorias. Passa-se, pois, a explicar no que consistiu tal equívoco.

\section{O DiAlógico, o PLURILÍngue E O POLIFônico}

Como forma de exemplificar o tipo de leitura adotado durante a pesquisa sobre os benandanti, Ginzburg transcreveu, ao término de seu primeiro livro, os autos do processo inquisitorial movido em face de Paolo Gasparutto e Batista Moduco. Obviamente que, durante o interrogatório, alternavam-se enunciados de inquisidores e acusados; alternância essa que, inclusive, se fazia notar graficamente nos documentos por meio do sinal de "travessão". Todavia, tal diálogo evidente, a que Bakhtin (1990b, p. 92) chama de externo-composicional, não exaure a possibilidade dialógica do texto em prosa. Não fosse assim, bastante restrita seria a análise da narratologia jurídica pelas categorias bakhtinianas de teoria literária.

Na verdade, um determinado discurso pode se apresentar totalmente desprovido de formas dialógicas externas de composição e, apesar disso (ou, até mesmo, indiferente a isso), se caracterizar como fortemente dialógico em razão de uma dialogização interna

15 Tal dialogismo diacrônico deve se somar ao dialogismo sincrônico que ocorre, em cada caso concreto, entre as partes e o juiz.

16 “(...) may be especially helpful when rigidly established limits between academic disciplines and fields of study are redefined or put into question" (NIKULIN, 1998, p. 381). Tive conhecimento do texto de Nikulin graças ao artigo Shakespeare e o direito de Vera Karam de Chueiri (2004). 
que se aperfeiçoa no objeto e(ou) na atitude responsivamente esperada do interlocutor. Em relação ao objeto, todo enunciado já o encontra, de algum modo,

desacreditado, contestado, avaliado, envolvido por sua névoa escura ou, pelo contrário, iluminado pelos discursos de outrem que já falaram sobre ele. O objeto está amarrado e penetrado por idéias gerais, por pontos de vista, por apreciações de outros e por entonações. Orientado para o seu objeto, o discurso penetra neste meio dialogicamente perturbado e tenso de discursos de outrem, de julgamentos e de entonações (BAKHTIN, 1990b, p. 86).

Assim, o discurso não encontra resistência apenas no objeto. Antes de atingi-lo, toca milhares de fios dialógicos circundantes, cada qual capaz de revelar ou ocultar algum ponto de vista sobre ele. A voz do autor que narra o objeto acaba sendo, em última instância, impregnada por diversas ressonâncias, ecos e entonações anteriormente proferidos sobre esse mesmo objeto. Apenas o Adão mítico poderia ter evitado por completo essa mútua-orientação dialógica do discurso alheio sobre o objeto e transitado por uma linguagem realmente neutra (BAKHTIN, 1990b, p. 88) - para todos os demais discursos históricos e concretos, isso seria impossível.

Surge, assim, uma dialogicidade interna que acaba sendo potencializada quando o discurso se orienta pela antecipação da atitude responsiva do destinatário. De certo modo, a resposta ao discurso, quer seja uma aquiescência, quer seja uma objeção motivada, mesmo quando meramente projetada, repercute na elaboração presente do próprio discurso. "O falante penetra no horizonte alheio de seu ouvinte, constrói a sua enunciação no território de outrem," (BAKHTIN, 1990b, p. 91) considerando suas expressões, acentos, entonações. Assim, para cada ouvinte real ou hipoteticamente considerado, surge um discurso permeado pela presença do outro, com quem se dialoga bem antes do efetivo diálogo.

Nesse sentido, a rigor, seria difícil apontar um texto monológico. Afinal, a todo tempo, o homem interroga, ouve, responde, concorda, transita por palavras alheias: a vida, por ela mesma, é um diálogo constante e inconcluso (BAKHTIN, 2006c, p. 348). Um diálogo, aliás, que ocorre entre vozes muitas vezes dissonantes. Da análise da pluralidade desses enunciados ditos nos mais diversos espaços dialógicos, fica perceptível uma estratificação da linguagem que decorre dos gêneros utilizados (oratórios, publicitários, jornalísticos, literários, dentre outros), do momento histórico e das condições pessoais do falante (profissão, classe social, idade). Assim, se, por um lado, o enunciado individual é marcado pelas forças de unificação da linguagem, que decorrem da vitória histórica de um dialeto proeminente sobre os demais, da canonização de regras e de seu ensino sistematizado, por outro, ele aponta para a resistência de um plurilinguismo, ou seja, a multiplicidade de pontos de vista específicos e verbalizáveis sobre o mundo que, expulsos da linguagem padronizada, nela re-entram pela enunciação do sujeito historicamente situado.

Por causa dessa estratificação, a língua na qual se dá o dialogismo não pode mais ser percebida como asséptica. Plena de entonações, a palavra da língua torna-se 
uma palavra semi-alheia. Ela só se torna 'própria' quando o falante a povoa com sua intenção, com seu acento, quando a domina através do discurso, torna-a familiar com a sua orientação semântica e expressiva. Até o momento em que foi apropriado, o discurso não se encontra em uma língua neutra e impessoal (pois não é do dicionário que ele é tomado pelo falante!), ele está nos lábios de outrem, nos contextos de outrem e a serviço das intenções de outrem; e é lá que é preciso que ele seja isolado e feito próprio (BAKHTIN, 1990b, p. 100).

Tal palavra apropriável do outro pode se apresentar de dois modos: autoritária ou interiormente persuasiva. A palavra autoritária recorda a palavra dos pais. Não sendo passível de ser selecionada, é encontrada de antemão e, apenas, reconhecida. Embora organize em torno de si massas de outras palavras, que a interpretam, que a exaltam, que a aplicam de uma ou outra forma, a palavra autoritária permanece nitidamente isolada em seu caráter monumental. Assim, ela entra na consciência verbal do sujeito como compacta e indivisível, confirmável ou recusável na íntegra, não admitindo variações livres e estilizantes (BAKHTIN, 1990b, p. 142-144).

Por outro lado, a palavra interiormente persuasiva revela possibilidades bastante diferentes. Compreendida e livremente assimilada, a palavra do outro entrelaça-se com a palavra do self, tornando-se metade própria metade alheia. Desse modo, livra-se da condição de isolamento e imobilidade, potencializa sua capacidade criativa, adapta-se ao jogo das fronteiras e permanece aberta, capaz de revelar continuamente todas as suas "novas possibilidade semânticas em cada um dos seus novos contextos dialogizados" (BAKHTIN, 1990b, p. 146).

Vê-se, pois, que o plurilinguismo social, revelador de uma pluralidade de visões de mundo, acaba se convertendo em força centrífuga que, ao tensionar a linguagem em seu processo de unificação, enriquece-a. No romance, segundo Bakhtin (1990b, p. 127), tal diversidade acaba sendo esteticizada de vários modos: no relato do narrador ou de um suposto autor, no discurso autônomo semântico-verbal das personagens ou, ainda, pela intercalação de gêneros. Todavia, em quaisquer desses modos, o plurilinguismo se mostra como o discurso de outrem na linguagem de outrem, mas de um modo capaz de refratar as intenções do autor. A palavra, nesse caso, torna-se bivocal, serve simultaneamente a dois locutores e exprime duas intenções diferentes: a intenção direta da personagem que fala e a intenção refrangida do autor.

Semelhante fenômeno ocorreu nos processos inquisitoriais conforme demonstrou Ginzburg (ainda que com impropriedade terminológica). Parafraseando Bakhtin, nos autos sobre os benandanti "estão espalhadas palavras, pequenos termos, definições e epítetos contaminados por intenções alheias, com as quais o inquisidor não se solidariza inteiramente e através das quais ele refrange suas próprias intenções"17. O próprio

${ }^{17}$ No original, a citação refere-se à linguagem de Turguêniev em seus romances: “estão espalhadas palavras, pequenos termos, definições e epítetos contaminados por intenções alheias, com as quais o autor não se solidariza inteiramente e através das quais ele refrange suas próprias intenções" (Bakhtin, 1990b, p. 120). 
desconhecimento sobre o real significado do termo benandante e, por consequência, de uma religiosidade popular complexa a ele vinculada, fez com que os inquisidores registrassem nos interrogatórios uma outra visão de mundo, distinta daquela das classes dominantes, quer quando transcreviam integralmente a fala dos acusados, quer quando a re-elaboravam sem falsear o que havia sido dito ${ }^{18}$. Os discursos de outrem na linguagem de outrem registrado nos autos inquisitoriais fizeram deles textos plurilíngues, permitindo com que o historiador rastreasse uma diversidade religiosa então existente - diversidade que não se mostrava perceptível na palavra autoritária dos tratados demonólogos.

Desse modo, não apenas os romances, mas também os processos judiciais podem se mostrar, para além de dialógicos, plurilíngues. A questão, nesses casos, é o modo como a linguagem do outro é considerada. Nos autos inquisitoriais, a surpresa dos inquisidores fez com que o registro mantivesse a substancialidade do discurso alheio. Nos processos judiciais ordinários, corre-se o risco de que a retórica torne a bivocalidade superficial, limitando-a a vitórias puramente verbais sobre a palavra, degenerando-a num jogo formalista de linguagem que se centra na palavra em si divorciada de seu contexto (BAKHTIN, 1990b, p. 152-153).

A superação de tal risco leva à percepção das várias vozes que se fazem audíveis em qualquer processo e de que maneira sua interação dialógica - ou o contraditório, caso se queira utilizar uma linguagem própria do campo jurídico - é que conduz o feito como seu elemento fundamental e inafastável. À luz desse novo paradigma, a sentença judicial não é uma narrativa escrita pelo juiz com exclusividade de linguagem. Na medida em que ele retoma argumentos e narrativas das partes que figuram no processo, quer como autores, quer como réus, ainda que dizendo-os novamente ao seu modo, as palavras da decisão são apenas parcialmente suas - uma metade de todas elas proveio do tecido dialógico de que é feito o horizonte histórico, o contexto social, o ordenamento jurídico e, principalmente, o processo judicial.

Ampliando o alcance jurídico da contribuição bakhtiniana, Mariela Vargova valeu-se da distinção entre palavra autoritária e interiormente persuasiva para questionar qual seria a compreensão atual acerca de um enunciado constitucional. Afinal, uma abordagem do texto constitucional como palavra autoritária levaria a uma compreensão originalista do mesmo, vinculando-o sempre ao passado e à intenção dos que o fizeram. A Constituição, nessa perspectiva, ganharia um status de documento historicamente distante e normativamente sagrado, de olhos fechados ao horizonte ético-cognitivo do contexto no qual seria lido e avesso, pois, a novas práticas interpretativas sociais (VARGOVA, 2007, p. 422).

18 “(...) relatar um texto com nossas próprias palavras é, até certo ponto, fazer um relato bivocal das palavras de outrem; pois as 'nossas palavras' não devem dissolver completamente a originalidade das palavras alheias, o relato com nossas próprias palavras deve trazer um caráter misto, reproduzir nos lugares necessários o estilo e as expressões do texto transmitido" (BAKHTIN, 1990b, p. 142). 
Do contrário, a percepção da Constituição como plurilíngue permitiria pensá-la como texto heterogêneo e aberto, pluralizando o conceito de normatividade constitucional, além de conectá-la diretamente a lutas e práticas de transformação sociais. A ostensiva dialogicidade do enunciado constitucional abriria possibilidades semânticas infinitas, tornando-o sensível a novos discursos e demandas sociais, mantendo-o em um estado permanente de criatividade e produtividade - convertendo-o, em resumo, numa constante ameaça a qualquer concepção autoritária, unitária, hierárquica e excludente da sociedade, da arte e da vida (VARGOVA, 2007, p. 423).

Essa última percepção, bastante convergente com a postura admitida por uma linha de pesquisa surgida na Faculdade de Direito da Universidade de Brasília, não referenciada na teoria literária ${ }^{19}$ e chamada Direito Achado na Rua, demonstra quão eticamente comprometida, crítica e oportuna pode ser uma leitura bakhtiniana do universo jurídico, o que mais uma vez justifica o presente artigo. Aclarada a distinção entre dialogismo e plurilinguismo, resta, por fim, explicar o que seja polifonia para dirimir o equívoco de Ginzburg.

Segundo Bakhtin, foi Dostoiévski quem deu origem ao romance polifônico, um gênero inteiramente novo marcado por uma multiplicidade de vozes e consciências independentes e imiscíveis que, não objetivadas, participam do grande diálogo romanesco em pé de absoluta igualdade. Nessa polifonia, o autor não reserva para si qualquer excedente de visão e, por consequência, não dá à personagem acabamento ou conclusibilidade. Do contrário, todas as qualidades objetivas estáveis da personagem "a sua posição social, a tipicidade sociológica e caracterológica, o habitus, o perfil espiritual e inclusive sua aparência externa" - ou seja, elementos de que se serve o autor para criar uma imagem rígida e estável da personagem, "tornam-se objeto de reflexão da própria personagem e objeto de sua autoconsciência" (BAKHTIN, 2008, p. 53).

O leitor e o autor não sabem nada a mais do que sabe a própria personagem sobre si própria. Tal autoconsciência faz com que a última palavra sobre o herói caiba a ele, o que o insere num plano ético de horizonte aberto, insolúvel e inconcluso. Assim, as personagens dialogicamente se constroem em discursos bivocais, podendo o autor apenas opor às mesmas a consciência de um outro com quem elas possam dialogar. Embora o autor seja um organizador ${ }^{20}$, ele não se põe acima do diálogo numa posição

${ }^{19}$ Não são ignoradas as citações literárias nos escritos de Roberto Lyra Filho, Roberto Aguiar e José Geraldo de Sousa Júnior, alguns dos autores utilizados pela referida linha de pesquisa. Porém, a preocupação em estabelecer uma crítica ao Direito sem se colocar fora dele fez com que as referências à literatura poucas vezes avançassem para densas referências à teoria literária - a exceção que confirma a regra é Luis Alberto Warat (2000) que trouxe para o direito o conceito bakhtiniano de carnavalização.

20 “O todo final em Dostoiévski é dialógico. Todas as personagens centrais são participantes do diálogo. Escutam tudo o que as outras dizem a seu respeito e a todas respondem (sobre elas nada é dito à revelia ou a portas fechadas). E o autor é apenas um participante do diálogo (o seu organizador)" (BAKHTIN, 2006c, p. 352). 
superior e decisiva, como se este se desse num passado concluído: "isto transformaria imediatamente o diálogo autêntico e inacabado em modelo material e acabado do diálogo, modelo comum a qualquer romance monológico ${ }^{21}$ " (BAKHTIN, 2008, p. 72). Desse modo, ele apenas garante para si o mínimo indispensável de excedente pragmático, puramente informativo e necessário à condução da narração (BAKHTIN, 2008, p. 83).

Partindo dessa percepção do romance polifônico, em que o outro narrado não é um ele, mas um $t u$ plenivalente, ou seja, "o plenivalente $e u$ de um outro (um tués)", fica difícil vislumbrar polifonia nos autos inquisitoriais. Os inquisidores não respeitavam os acusados como autoconsciências, punham-se acima do diálogo numa posição superior e decisiva, mantinham para si a última palavra sobre a caracterização do outro como feiticeiro, dando-lhe um acabamento muitas vezes questionável. Na verdade, o plurilinguismo nos processos sobre os benandanti não garantiu uma polifonia, pois esta exige observância da alteridade, uma postura discursiva de igual respeito e consideração e o direito de cada um participar efetivamente da narrativa sobre si mesmo.

Ampliando, porém, a reflexão para o campo do direito resta o questionamento: as decisões judiciais como narrativas jurídicas podem ser polifônicas? De fato, o juiz não parece ser apenas um organizador do diálogo. As partes que litigam entre si em juízo vivem plenamente no plano ético-cognitivo, orientando seus atos no acontecimento aberto da existência. Porém, a decisão judicial, como narrativa jurídica (e objeto estético), precisa promover um corte nesse acontecimento inconcluso, a fim de que o acabamento promova a decidibilidade necessária. Obviamente que a polifonia pode (e deve) se colocar como um horizonte para o processo em si: isso radicalizará o dialogismo e uma atitude mútua respeitosa e responsável entre todos os atores judiciais, bem como evitará que a esteticização das partes, que entram na narrativa jurídica como personagens, leve à objetivação pura e simples delas, reduzindo-as a uma imagem de si forjada sem a contribuição de suas autoconsciências.

Ocorre, porém, que em algum momento o juiz precisa narrar os fatos e dar-lhes conclusibilidade, o que compromete a plena realização da polifonia. Como o acabamento só se realiza na medida em que o autor possui um substancial excedente de visão em relação a todas as personagens de sua narrativa, o juiz acaba por não se colocar no mesmo patamar das partes que julga. Desse modo, mais do que gerar uma compreensão relativa à maneira como se tece tal trama nas instâncias judiciais, legitimando-a, a "polifonia" revela o quanto uma categoria da teoria literária pode apresentar potencialidade crítica para a reflexão do direito. Afinal, se a narrativa jurídica proferida pelo Judiciário

${ }^{21}$ Embora muitas vezes conste no referido livro a dualidade monológico/dialógico, o tradutor Paulo Bezerra faz questão de ressaltar em algumas passagens que monológico equivale a homofônico, em oposição a polifônico. Afinal, é possível um romance homofônico e dialógico (no sentido acima explicitado de dialogismo). 
não consegue garantir a absoluta igualdade polifônica, talvez seja evidente a necessidade cada vez maior de se estimular formas alternativas e horizontais de solução de conflitos, tais como a mediação.

\section{INQUIETAÇÕES INCONCLUSAS}

Não se pretende, ao final do presente artigo, apresentar um rol das sínteses alcançadas. Afinal, as conclusões foram se construindo de tal modo dialógico no decorrer da argumentação que tão somente enumerá-las poderia gerar demasiada simplificação. Pretende-se, porém, restando demonstrada a proficuidade de uma teoria narrativa do direito, bem como a pertinência metodológica de leitura das decisões e autos judiciais à luz das categorias bakhtinianas da teoria literária, apontar algumas inquietações quanto ao mais evidente autor jurídico, deixando aberta tal investigação para futuras incursões.

Se o autor da narrativa não-polifônica é caracterizado por sua exotopia, seu excedente de visão em relação às personagens, o que lhe permite envolvê-las e seus horizontes ético-cognitivos dando-lhes acabamento, no campo do direito o principal autor será o Supremo Tribunal Federal (STF). Afinal, a Corte Constitucional, posta hierarquicamente numa posição superior aos demais juízes e tribunais, detém maior poder de conclusibilidade em relação às narrativas jurídicas produzidas, caracterizandose, assim, como autor de maior visão transgrediente no Poder Judiciário ${ }^{22}$.

Todavia, não há, na verdade, uma única narrativa escrita pelo STF a cada nova decisão. Haveria se os casos fossem precedidos de um debate argumentativo e que, da orientação vencedora, decorresse um texto coeso e único, ainda que com ressalvas das divergências. Todavia, pela atual lógica da corte, cada nova decisão pode gerar onze narrativas distintas, uma para cada Ministro que a integra. Tal situação, embora apontada como inconsistente por alguns autores ${ }^{23}$, revela um aspecto extremamente sutil da relação autor-personagem nas decisões da Corte.

Segundo Bakhtin (2006b, p. 4-6; 2006d, p. 399), o autor-criador é encontrado no momento inseparável em que o conteúdo e a forma se fundem intimamente. Durante a elaboração da obra, a personagem vai se desvelando, dialogicamente respondendo à

${ }^{22}$ Não se desconhece o fato de que, numa sociedade aberta, todas as forças pluralísticas públicas constituemse forças produtivas de interpretação, pré-intérpretes fundamentais no processo de descoberta e de obtenção do direito (HÄBERLE, 2002, p. 41-43). Todavia, metodologicamente, o presente trabalho orienta-se pelas narrativas jurídicas produzidas pelo Poder Judiciário, assim como Ginzburg se orientou pelos autos inquisitoriais.

${ }^{23}$ A título de exemplo, cita-se: "Na realidade o que o sistema jurídico necessita são decisões que correspondam a um maior consenso decorrente de um intenso processo de discussão e deliberação da Corte. Evidente que sempre deverá haver espaço para votos discordantes e opiniões complementares, mas a maioria deveria ser capaz de produzir uma decisão acordada, um acórdão, que representasse a opinião do Tribunal. Isto daria mais consistência a decisões judiciais de grande impacto político" (VIEIRA, 2008, p. 75). 
posição emocional-volitiva do autor até que se constitua de modo estável e integral ${ }^{24}$. Concluído o objeto estético, nada tem o artista a dizer sobre seu processo de criação, todo situado no produto criado; resta a ele apenas indicar a própria obra. Ao falar para além da obra criada, substitui sua atitude efetivamente criadora, não vivida por ele na alma mas realizada na obra, por uma atitude nova, receptiva e contemplativa daquilo que criou. Nesse momento, quem fala é o autor-pessoa: o autor-criador, presente no todo da obra, já conquistou sua autonomia.

Esse autor-criador, também chamado de autor primário, embora manifesto no todo daquilo que criou, não se situa internamente na própria narrativa - afinal, em relação à obra, ele é a natureza não criada que cria. $\mathrm{O}$ autor secundário ou imagem do autor é que, natureza criada que também cria, se insere na obra de forma imanente ${ }^{25}$. "O autor secundário, mesmo sendo imagem, é imagem de autor que cria de dentro da própria obra, e ao mesmo tempo é personagem que integra a estrutura da obra, cria personagens, dialoga e interage com elas" (BEZERRA, 2005, p. 77). Como o "autorcriador não pode ser criado na esfera em que ele próprio é o criador" (BAKHTIN, 2006d, p. 400), autores primário e secundário não convivem no mesmo espaço da criação: na narrativa, só a imagem do autor é visível, na condição dúplice de personagem criado e autor de personagens e tramas.

Em relação às narrativas jurídicas, a pluralidade de votos proferidos ${ }^{26} \mathrm{em}$ cada caso submetido a julgamento perante o Supremo Tribunal Federal parece convertê-lo em autor secundário formalmente exigido em todas essas situações, ao passo que os Ministros permaneceriam, no mais das vezes, na condição de autores primários. Como autor secundário de uma trama, o STF acaba por ecoar a voz do próprio autor primário, o que não parece tão problemático. Mas, na medida em que ele entra na trama como um personagem criado, invocado sucessivamente em cada narrativa e passível de ser desvelado progressivamente a cada uma delas, surge a pergunta: quem é o guardião da Constituição? Quem é esse autor/personagem, quais suas características e como elas foram sendo estabilizadas de forma encadeada desde a redemocratização?

24 "Quando Charles deixou Sarah na beira do penhasco, ordenei-lhe que fosse diretamente para Lyme Regis. Mas ele não foi; sem motivo algum, voltou-se e foi para a Leiteria. Ora, o que é isso, você dirá - o que realmente quero dizer é que, enquanto escrevia, passou pela minha cabeça que talvez fosse mais engenhoso fazê-lo parar para tomar leite... e encontrar Sarah outra vez. Isso certamente é uma explicação do que aconteceu, mas só posso dizer - e sou a prova mais confiável - que a ideia claramente pareceu vir de Charles, não de mim" (FOWLES apud DWORKIN, 2005, p. 232).

25 "Podemos citar os seguintes exemplos de autores secundários ou imagens de autor na literatura brasileira: Aires em Esaú e Jacó, e Brás Cubas, o defunto autor de Memórias póstumas de Brás Cubas, de Machado de Assis; Paulo Honório em São Bernardo, de Graciliano Ramos; Rodrigo S.M. em A hora da estrela, de Clarice Lispector" (BEZERRA, 2008, p. 77).

${ }^{26}$ Ainda que um determinado caso possa ser decidido com um voto único ratificado pelos demais Ministros, a pluralidade de narrativas sempre permanece, ao menos, como possibilidade. 
Uma resposta adequada exigiria uma retomada do debate constituinte de 19871988, que culminou na escolha do STF como guardião constitucional, bem como das narrativas que se seguiram nas décadas seguintes, especialmente as construídas por decisões proferidas pela própria Corte Constitucional a respeito de sua competência jurisdicional e as decorrentes de emendas constitucionais reformadoras do Poder Judiciário aprovadas pelo Congresso Nacional. Tal acervo disponível deveria ser analisado por meio de uma leitura minuciosamente detida.

Ginzburg, esclarecendo tal método, cita como inspiradora a participação em um seminário ministrado por Delio Cantimori no qual, durante uma semana inteira, foram estudadas doze linhas de um texto de Burckhardt - aliás, tão inspiradora que ele admite utilizar a mesma estratégia atualmente ${ }^{27}$. Óbvio que a prática da leitura lenta não é importante em si mesma, mas pelo favorecimento de uma observação das entrelinhas, dos discursos bivocais e do plurilinguismo reveladores de um dialogismo interno, fazendo com que a atitude de como se debruçar sobre o texto integre a própria metodologia de estudo do texto, assim como desenvolvido pelo historiador no caso dos benandanti.

Em recente trabalho, Paulo Maia (2008) demonstrou como uma decisão do STF, em sede de Arguição de Descumprimento de Preceito Fundamental, apontava para a autocompreensão da Corte Constitucional como tribunal político. $\mathrm{O}$ artigo partia de um referencial luhmaniano e procurava estabelecer os riscos de uma indistinção entre os sistemas político e jurídico. Todavia, o que o autor chama de autocompreensão parece, conforme acima demonstrado, mais um desvelamento da personagem dado pelo autorcriador no processo de tecedura da trama constitucional. Rastrear que outras características já foram construídas nessa narrativa, bem como as circunstâncias em que o foram, pode clarificar os contornos dessa personagem, a quem se reconhece legitimidade de autor na arte da vida democrática. Sobre isso, pretendo escrever numa outra ocasião.

\section{REFERÊNCIAS}

BAKHTIN, Mikhail. O problema do conteúdo, do material e da forma na criação literária. In: Questões de literatura e de estética: a teoria do romance. 2. ed. Tr. Aurora Fornoni Bernardini et alli. São Paulo: Hucitec/Unesp, 1990a.

BAKHTIN, Mikhail. O discurso no romance. In: Questões de literatura e de estética: a teoria do romance. 2. ed. Tr. Aurora Fornoni Bernardini et alli. São Paulo: Hucitec/Unesp, 1990b.

BAKHTIN, Mikhail. Arte e responsabilidade. In: Estética da criação verbal. 4. ed., $2^{\mathrm{a}}$ tir. Tr. Paulo Bezerra. São Paulo: Martins Fontes, 2006a (Col. Biblioteca Universal).

27 "Recentemente, comecei um seminário na UCLA dizendo aos meus alunos: 'Na Itália há um novo movimento chamado Slow Food, em oposição ao Fast Food. Meu seminário será em Slow Reading'. (...) Realmente gosto muitíssimo da idéia de leitura vagarosa" (GINZBURG, 2000, p. 275). 
BAKHTIN, Mikhail. O autor e a personagem na atividade estética. In: Estética da criação verbal. 4. ed., $2^{\text {a }}$ tir. Tr. Paulo Bezerra. São Paulo: Martins Fontes, 2006b (Col. Biblioteca Universal).

BAKHTIN, Mikhail. Reformulação do livro sobre Dostoiévski. In: Estética da criação verbal. 4. ed., $2^{\mathrm{a}}$ tir. Tr. Paulo Bezerra. São Paulo: Martins Fontes, 2006c (Col. Biblioteca Universal).

BAKHTIN, Mikhail. Metodologia das ciências humanas. In: Estética da criação verbal. 4. ed., $2^{\mathrm{a}}$ tir. Tr. Paulo Bezerra. São Paulo: Martins Fontes, 2006d (Col. Biblioteca Universal).

BAKHTIN, Mikhail. Problemas da poética de Dostoiévski. 4. ed. rev. e ampl. Tr. Paulo Bezerra. Rio de Janeiro: Forense Universitária, 2008.

BAKHTIN, Mikhail; MEDVEDEV, Pavel Nikolaevich. The formal method in literary scholarship: a critical introduction to sociological poetics. Tr. Albert J. Wehrle. Baltimore/London: The Johns Hopkins University Press, 1991.

BEZERRA, Paulo. Dialogismo e autoria. In: Dostoiévski: "Bobók". Tradução e análise do conto. São Paulo: Editora 34, 2005.

CHKLOVSKI, Viktor. A arte como procedimento. In: TOLEDO, Dionísio de Oliveira (Org.). Teoria da literatura: formalistas russos. Porto Alegre: Globo, 1973.

CHUEIRI, Vera Karam de. Shakespeare e o direito. Revista da Faculdade de Direito da Universidade Federal do Paraná. Curitiba: SER/UFPR, 2004.

CHUEIRI, Vera Karam de. Kafka, Shakespeare e Graciliano: tramando o Direito. Revista da Faculdade Mineira de Direito. Belo Horizonte, v. 10, n. 19, jan./jun. 2007.

DWORKIN, Ronald. O império do direito. Tr. Jefferson Luiz Camargo. São Paulo: Martins Fontes, 1999 (Ensino superior).

DWORKIN, Ronald. De que maneira o direito se assemelha à literatura. In: Uma questão de princípio. 2. ed. Tr. Luís Carlos Borges. São Paulo: Martins Fontes, 2005 (Justiça e direito).

GINZBURG, Carlo. História e cultura: conversa com Carlo Ginzburg. Tr. Dora Rocha Flaksman. Estudos históricos. Rio de Janeiro, v. 3, n. 6, 1990.

GINZBURG, Carlo. O inquisidor como antropólogo. Revista Brasileira de História. Tr. Jônatas Batista Neto. São Paulo, v. 11, n. 21, set. 1990/fev. 1991.

GINZBURG, Carlo. Entrevista. In: PALLARES-BURKE, Maria Lúcia Garcia. As muitas faces da história: nove entrevistas. São Paulo: UNESP, 2000.

GINZBURG, Carlo. Olhos de madeira: nove reflexões sobre a distância. Tr. Eduardo Brandão. São Paulo: Companhia das Letras, 2001.

GINZBURG, Carlo. Relações de força: história, retórica, prova. Tr. Jônatas Batista Neto. São Paulo: Companhia das Letras, 2002.

GINZBURG, Carlo. Os andarilhos do bem: feitiçaria e cultos agrários nos séculos XVI e XVII. $2^{\mathrm{a}} \mathrm{ed}$. Tr. Jônatas Batista Neto. São Paulo: Companhia das Letras, 2007a.

GINZBURG, Carlo. O fio e os rastros: verdadeiro, falso, fictício. Tr. Rosa Freire d 'Aguiar e Eduardo Brandão. São Paulo: Companhia das Letras, 2007b.

GINZBURG, Carlo. O queijo e os vermes: o cotidiano e as idéias de um moleiro perseguido pela Inquisição. Tr. Maria Betânia Amoroso e José Paulo Paes. São Paulo: Companhia das Letras, 2008 (Companhia de Bolso). 
HÄBERLE, Peter. Hermenêutica constitucional. A sociedade aberta dos intérpretes da Constituição: contribuição para a interpretação pluralista e "procedimental" da Constituição. $1^{\text {a }}$ reimpr. Tr. Gilmar Ferreira Mendes. Porto Alegre: Sergio Antonio Fabris Editor, 2002.

MAIA, Paulo Sávio Peixoto. O Supremo Tribunal Federal como "tribunal político": observações acerca de um lugar comum do direito constitucional. Revista de Informação Legislativa. Brasília, v. 45 , n. 180 , out./dez. 2008.

MELLO, Cláudio Ari. Democracia constitucional e direitos fundamentais. Porto Alegre: Livraria do Advogado Editora, 2004.

NIKULIN, Dimitri. Mikhail Bakhtin: a theory of dialogue. Constellations. Oxford/Malden, v. 5, n. 3, 1998.

PAIXÃO, Cristiano; BIGLIAZZI, Renato. História constitucional inglesa e norte-americana: do surgimento à estabilização da forma constitucional. Brasília: Editora da Universidade de Brasília/ Finatec, 2008.

SCHNAIDERMAN, Boris. Prefácio. In: TOLEDO, Dionísio de Oliveira (Org.). Teoria da literatura: formalistas russos. Porto Alegre: Globo, 1973.

SHATSKIKH, Aleksandra Semenovna. Vitebsk: the life of art. Tr. Katherine Foshko Tsan. New Haven/London: Yale University Press, 2007.

VARGOVA, Mariela. Dialogue, pluralism, and change: the intertextual Constitution of Bakhtin, Kristeva, and Derrida. Res Publica. Liverpool, v. 12, n. 4, dezembro/2007.

VESPAZIANI, Alberto. Per un'ermeneutica della metafora giuridica. Bologna: Italian Society for Law and Literature, 2009.

VIEIRA, Oscar Vilhena. Supremocracia. Revista de Direito do Estado. Rio de Janeiro, a. 3, n. 12, out./dez. 2008.

WARAT, Luis Alberto. A ciência jurídica e seus dois maridos. 2. ed. Santa Cruz do Sul: EDUNISC, 2000. 
